\title{
Differential diagnosis of Brucella abortus by real-time PCR based on a single-nucleotide polymorphisms
}

\author{
Ji-Yeon KIM ${ }^{1,3) \#, ~ S u n g-I l ~ K A N G ~}{ }^{1 \#}$, Jin Ju LEE ${ }^{1)}$, Kichan LEE $^{1)}$, So-Ra SUNG ${ }^{1)}$, Janchivdorj ERDENEBAATAAR ${ }^{2)}$, \\ Batbaatar VANAABAATAR ${ }^{2)}$, Suk Chan JUNG ${ }^{1)}$, Yong Ho PARK ${ }^{3)}$, Han-Sang YOO $^{3)}$ and Moon HER ${ }^{1) *}$ \\ 1) Animal and Plant Quarantine Agency, 175 Anyang-ro, Anyang-city, Gyeonggi-do, 430-757, Republic of Korea \\ ${ }^{2)}$ Institute of Veterinary Medicine, Zaisan 17024, Ulaanbaatar, Mongolia \\ ${ }^{3)}$ Seoul National University, Gwanak-ro 1, Gwanak-gu, Seoul, 151-742, Republic of Korea
}

(Received 14 September 2015/Accepted 28 November 2015/Published online in J-STAGE 14 December 2015)

ABSTRACT. To diagnose brucellosis effectively, many genus- and species-specific detection methods based on PCR have been developed. With conventional PCR assays, real-time PCR techniques have been developed as rapid diagnostic tools. Among them, real-time PCR using hybridization probe (hybprobe) has been recommended for bacteria with high DNA homology among species, with which it is possible to make an accurate diagnosis by means of an amplification curve and melting peak analysis. A hybprobe for B. abortus was designed from a specific single-nucleotide polymorphism (SNP) on the $f b a A$ gene. This probe only showed specific amplification of $B$. abortus from approximately the 14 th cycle, given a melting peak at $69^{\circ} \mathrm{C}$. The sensitivity of real-time PCR was revealed to be $20 \mathrm{fg} / \mu \mathrm{l}$ by 10 -fold DNA dilution, and the detection limit was 4 CFU in clinical samples. This real-time PCR showed greater sensitivity than that of conventional PCR and previous real-time PCR based on Taqman probe. Therefore, this new real-time PCR assay could be helpful for differentiating $B$. abortus infection with rapidity and accuracy.

KEY WORDS: Brucella abortus, fbaA gene, hybprobe, real-time PCR, SNP

doi: 10.1292/jvms.15-0541; J. Vet. Med. Sci. 78(4): 557-562, 2016

Brucellosis is known as a major zoonotic disease that can cause reproductive problems, such as abortion, stillbirth or infertility in livestock and wild animals [14, 27]. The genus Brucella consists of ten species; six species (Brucella abortus, B. melitensis, B. suis, B. canis, B. ovis and B. neotomae) considered classic members and four species (B. ceti, B. pinnipedialis, B. microti and B. inopinata) considered atypical types of Brucella. So far, classification of Brucella species has been mainly based on host preferences and classical phenotypic biotyping $[14,26]$. Moreover, the genus expansion is still being processed, with the recent addition of $B$. papionis from baboons [26].

In terms of the diagnosis of brucellosis, serological assays and bacterial cultivation have mainly been used. Serologic methods are very sensitive and rapid methods to perform, but sometimes false-positive reactions occur with crossreactive bacteria, such as Yersinia enterocolitica O:9, due to the similar structure of the O-chain in the smooth lipopolysaccharide portion $[2,8]$. In contrast, bacterial culture is considered a 'gold standard' with high specificity, but it is time-consuming and also requires a highly trained workforce and a well-equipped laboratory due to the biohazard

*Correspondence to: Her, M., OIE Reference Laboratory for Brucellosis, Bacterial Disease Division, Animal and Plant Quarantine Agency, Ministry for Food, Agriculture, Forestry and Fisheries, Gyeonggi-do, Anyang, 430-757, Republic of Korea. e-mail: herm@korea.kr

\#These authors contributed equally to this work.

C 2016 The Japanese Society of Veterinary Science

This is an open-access article distributed under the terms of the Creative Commons Attribution Non-Commercial No Derivatives (by-nc-nd) License $<$ http://creativecommons.org/licenses/by-nc-nd/4.0/>. risks with Brucella [25].

To overcome these disadvantages, molecular detection methods have been introduced as an alternative for diagnosing brucellosis. Many genus- or species-specific PCR assays, using 16S rRNA and the bcsp31, IS711 and omp2 genes, have been developed [3-5, 7, 8]. Additionally, various multiplex PCRs that can differentiate at the species level have been established $[10,12,13]$. All of these molecular detection methods are very effective for detecting Brucella strains [20]. Since the development of conventional PCR assays, real-time PCR and loop-mediated isothermal amplification assay (LAMP)-PCR have been introduced as rapid diagnostic tools. Recently, the application of single nucleotide polymorphisms (SNPs) in the microbiological field has shown some merits for diagnosing bacteria with high homology of their DNA [21]. SNP-based PCR assays have been introduced for differentiating bacterial strains and species [14].

Here, we developed a new real-time PCR assay with a hybprobe from a specific SNP to distinguish B. abortus from other Brucella species. Real-time PCR assay using this hybprobe could diagnose rapidly, using an amplification curve with real-time monitoring, and exactly, using melting peak analysis [7], so it is expected to provide more sensitive, rapid and accurate diagnostic efficiency in detecting $B$. abortus infection.

\section{MATERIALS AND METHODS}

Bacterial strains and DNA samples: A total of 296 Brucella strains were included: 22 Brucella reference strains; 110 Mongolian isolates (16 B. abortus and 94 B. melitensis); 
Table 1. Bacterial strains used in this study and comparison of the two conventional PCR methods

\begin{tabular}{|c|c|c|c|c|}
\hline \multirow{2}{*}{ Species } & \multirow{2}{*}{ Strains } & \multicolumn{3}{|c|}{ PCR results } \\
\hline & & 16S rRNA & BaSS & Realtime PCR \\
\hline \multicolumn{5}{|l|}{ Brucella species } \\
\hline B. abortus bv. 1 (544) & ATCC 23448 & + & + & + \\
\hline B. abortus bv. $2(86 / 8 / 59)$ & ATCC 23449 & + & + & + \\
\hline B. abortus bv. 3 (Tulya) & ATCC 23450 & + & $\pm^{\text {a) }}$ & + \\
\hline B. abortus bv. 4 (292) & ATCC 23451 & + & + & + \\
\hline B. abortus bv. 5 (B3196) & ATCC 23452 & + & \pm & + \\
\hline B. abortus bv. $6(870)$ & ATCC 23453 & + & \pm & + \\
\hline B. abortus bv. 9 (C68) & ATCC 23455 & + & \pm & + \\
\hline B. canis (RM6/66) & ATCC 23365 & + & \pm & - \\
\hline B. suis bv. 1 (1330) & ATCC 23444 & + & \pm & - \\
\hline B. suis bv. 2 (Thomsen) & ATCC 23445 & + & \pm & - \\
\hline B. suis bv. 3 (686) & ATCC 23446 & + & \pm & - \\
\hline B. suis bv. 4 (40) & ATCC 23447 & + & \pm & - \\
\hline B. suis bv. 5 (513) & NCTC 11996 & + & \pm & - \\
\hline B. ovis $(63 / 290)$ & ATCC 25840 & + & \pm & - \\
\hline B. neotomae (5K33) & ATCC 23459 & + & \pm & - \\
\hline B. melitensis bv. $1(16 \mathrm{M})$ & ATCC 23456 & + & \pm & - \\
\hline B. melitensis bv. $2(63 / 9)$ & ATCC 23457 & + & \pm & - \\
\hline B. melitensis bv. 3 (Ether) & ATCC 23458 & + & \pm & - \\
\hline B. ceti (B1/94) & NCTC 12891 & + & \pm & - \\
\hline B. pinnipedialis (B2/94) & NCTC 12890 & + & \pm & - \\
\hline B. microti (CCM 4915) & BCCN 07-01 & + & \pm & - \\
\hline B. inopinata (B01) & BCCN 09-01 & + & \pm & - \\
\hline Mongolian B. abortus & 16 isolates & + & \pm & + \\
\hline Mongolian B. melitensis & 94 isolates & + & \pm & - \\
\hline Korean B. abortus & 84 isolates & + & + & + \\
\hline Korean $B$. canis & 72 isolates & + & \pm & - \\
\hline \multicolumn{5}{|l|}{ Non-Brucella organisms } \\
\hline Ochrabactrum anthropi & Field strain & + & - & - \\
\hline Escherichia coli $\mathrm{O} 157: \mathrm{H} 7$ & Field strain & - & - & - \\
\hline Pasteurella multocida & ATCC 43017 & - & - & - \\
\hline Salmonella Typhimurium & ATCC 14028 & - & - & - \\
\hline Campylobacter jejuni & ATCC 33560 & - & - & - \\
\hline Yersinia enterocolitica O:9 & NCTC 11174 & - & - & - \\
\hline Staphylococcus aureus & Field strain & + & - & - \\
\hline Clostridium perfringens type $\mathrm{A}$ & ATCC 13124 & - & - & - \\
\hline
\end{tabular}

$\left.\pm^{\mathrm{a}}\right)$ : They were identified with Brucella spp. showing two amplified products (180 bp and $800 \mathrm{bp}$ ).

156 Korean isolates ( 84 B. abortus and 72 B. canis); and 8 non-Brucella strains reported to be serologically crossreactive or phylogenetically similar bacteria (Table 1). $B$. abortus and $B$. melitensis from Mongolia were provided by Institute of Veterinary Medicine (IVM), through a collaborative project conducted from 2012 to 2014 . The isolates from Mongolia were B. abortus biovar (bv.) 3 (9 strains) and untype (7) and B. melitensis bv. 1 (67), bv. 3 (10) and Rev. 1 (17). In addition, all of the Korean $B$. abortus bv. 1 was obtained from slaughtered cattle with brucellosis beginning in 2008 , and the $B$. canis was from dog-breeding farms during 2002-2011. All of the Brucella isolates were identified by the classical biotyping assay including colony morphology, lysis by phages, oxidase, urease activity, growth on dyes and agglutination with monospecific sera (anti-A, -M and -R) [24] and also confirmed specific bands for Brucella species by the differential multiplex PCR [10]. Genomic DNA for real-time PCR was extracted using a Blood \& Tissue kit (Qiagen Ltd., Seoul, South Korea) per the manufacturer's instructions.

Hybprobe design and real-time PCR conditions: To develop $B$. abortus-specific real-time PCR assays, comparative sequence analysis, using $f b a A$ gene region in whole genome sequences and/or partial sequences of 22 Brucella reference strains, was performed with the CLC Main Workbench software program version 6.0 (Insillicogen Inc., Aarhus N, Denmark). Based on the new B. abortus-specific SNP sites, the primer and probe sets were designed and developed using BEACON designer (Sigma-Aldrich, St. Louis, MO, U.S.A.).

Real-time PCR with hybprobe was performed using 4.0 $\mu l$ of $5 \times$ genotyping master mix, $0.5 \mu l$ of each primer, 0.3 $\mu l$ of each hybprobe, $13.4 \mu l$ of D.W. and $1.0 \mu l$ of DNA in 
Table 2. Direct detection from clinical specimens of brucellosis-positive Korean native cattle by real-time PCR

\begin{tabular}{clcccc}
\hline \multirow{2}{*}{ Sample No. } & \multicolumn{1}{c}{ Specimen } & \multirow{2}{*}{ Isolation $^{\mathrm{a})}$} & \multirow{2}{*}{$\mathrm{RBT}^{\mathrm{b})}$} & \multicolumn{2}{c}{ Real-time PCR } \\
\cline { 5 - 6 } & & & & Mean Ct & $\mathrm{Tm}$ \\
\hline 1 & Buffy coat & + & + & 16.89 & 69.43 \\
2 & Buffy coat & + & + & 16.88 & 69.41 \\
3 & Calf submandibular LN $\left.{ }^{\mathrm{c}}\right)$ & + & $\mathrm{NT}^{\mathrm{d}}$ ) & 29.24 & 69.23 \\
4 & Submandibular LN-1 & + & + & 28.45 & 69.46 \\
5 & Submandibular LN-2 & + & + & 29.28 & 69.15 \\
6 & Submandibular LN-3 & + & + & 29.74 & 69.42 \\
7 & Submandibular LN-4 & + & + & 28.79 & 69.38 \\
8 & Submandibular LN-5 & + & + & 29.13 & 69.08 \\
9 & Supramammary LN & + & + & 28.89 & 69.41 \\
10 & Calf inguinal LN & + & $\mathrm{NT}$ & 29.29 & 69.06 \\
11 & Parotid LN & + & - & 29.27 & 69.13 \\
12 & Testicle & + & + & 28.65 & 69.34 \\
\hline
\end{tabular}

a) Isolation: The bacterial strains were identified by classical phenotyping and differential multiplex PCR (Kang et al., 2011). b) RBT: Rose-Bengal test. c) LN: Lymph node. d) NT: Not tested.

Table 3. Primers and probes for detection of B. abortus using specific SNPs

\begin{tabular}{lllc}
\hline & & \multicolumn{1}{c}{ Sequence $\left(5^{\prime}-3^{\prime}\right)$} & Comment \\
\hline Primer & $\begin{array}{llll}\text { Forward } \\
\text { Reverse }\end{array}$ & GATGCGCCGGTTATCCTG & 176 bp size \\
\hline Probe & $\begin{array}{l}\text { Anchor } \\
\text { Sensor }\end{array}$ & $\begin{array}{l}\text { ACGGAGCAGCCGCATGGGTCATTGGCATAGGAACG } \\
\text { ATAGATCCGC }{ }^{*} \text { CACGGCATCCATC }\end{array}$ & SNP site $^{\text {a) }}$ \\
\hline
\end{tabular}

a) Single nucleotide polymorphism.

a $20 \mu l$ total volume. After centrifugation for the removal of bubbles from the PCR plate, amplification and melting curve analysis were conducted using a LightCycler ${ }^{\circledR}$ 480II (Roche Diagnostic, Mannheim, Germany). The real-time PCR amplification was performed with an initial denaturation step of $95^{\circ} \mathrm{C}$ for $5 \mathrm{~min}$, followed by 45 cycles of $95^{\circ} \mathrm{C}$ for $10 \mathrm{sec}$, $65^{\circ} \mathrm{C}$ for $15 \mathrm{sec}$ and $68^{\circ} \mathrm{C}$ for $15 \mathrm{sec}$. After amplification, melting analysis was performed at between $40^{\circ} \mathrm{C}$ and $80^{\circ} \mathrm{C}$ at a rate of increase of $0.1^{\circ} \mathrm{C}$.

Specificity and sensitivity of real-time PCR assay: The specificity of real-time PCR assay using 22 Brucella reference strains, Brucella isolates and non-Brucella bacteria was assessed (Table 1). Its sensitivity was determined from a DNA concentration of $1 n \mathrm{~g} / \mu l$ to $1 \mathrm{fg} / \mu l$ by serial 10 -fold dilution of the $B$. abortus 544 reference strain. DNA concentration was measured using a Nanodrop ND-1000 UV/ UVS spectrophotometer (Nanodrop Tech., Wilmington, DE, U.S.A.). These results were compared with those of a $16 \mathrm{~S}$ rRNA [20] and BaSS-PCR assays [3], which were used to identify Brucella species and B. abortus biovars 1, 2 and 4 conventionally.

Detection limits of real-time PCR assay: To compare the analytical sensitivity of real-time PCR assay in the clinical specimens, artificial inoculation using a $B$. abortus strain in the clinical samples was conducted. Briefly, ten-fold serial dilutions of the $B$. abortus strain with $0.85 \%$ saline were processed into the macerated lymphoid tissue, and then, each spiked sample was cultivated on three tryptic soy agars and was calculated in colony-forming units (CFU). The DNA of the spiked samples was extracted using a commercial blood and tissue kit (Qiagen Ltd.) according to the manufacturer's protocols.

Evaluation of real-time PCR assay: To apply real-time PCR assay to the clinical specimens, twelve samples (supramammary, submandibular, inguinal and parotid lymph nodes, testicle and buffy coat) were acquired from seropositive Korean native cattle on a breeding farm (Table 2). These specimens were ground in $1 \mathrm{~m} l$ of PBS buffer and spread onto tryptic soy agar supplemented with $5 \%$ bovine serum (GIBCO, Grand Island, NY, U.S.A.) and 5\% sheep blood agar for 3-4 days at $37^{\circ} \mathrm{C}$ and $5 \% \mathrm{CO}_{2}$. Genomic DNA from $200 \mu \mathrm{l}$ of ground sample was extracted using a Blood \& Tissue kit (Qiagen Ltd.) per the manufacturer's instructions and was submitted to real-time PCR assay.

\section{RESULTS}

B. abortus-specific SNPs were detected at the $f b a A$ gene of $B$. abortus chromosome II (Genbank accession No. AE 017224), with cytosine changed to thymine at 360432 on $B$. abortus chromosome II. Based on the sequence of the $\mathrm{fbaA}$ gene, a primer set $176 \mathrm{bp}$ in size and a hybprobe with a specific SNP were designed (Table 3 ).

Real-time PCR assay showed a positive reaction only to 

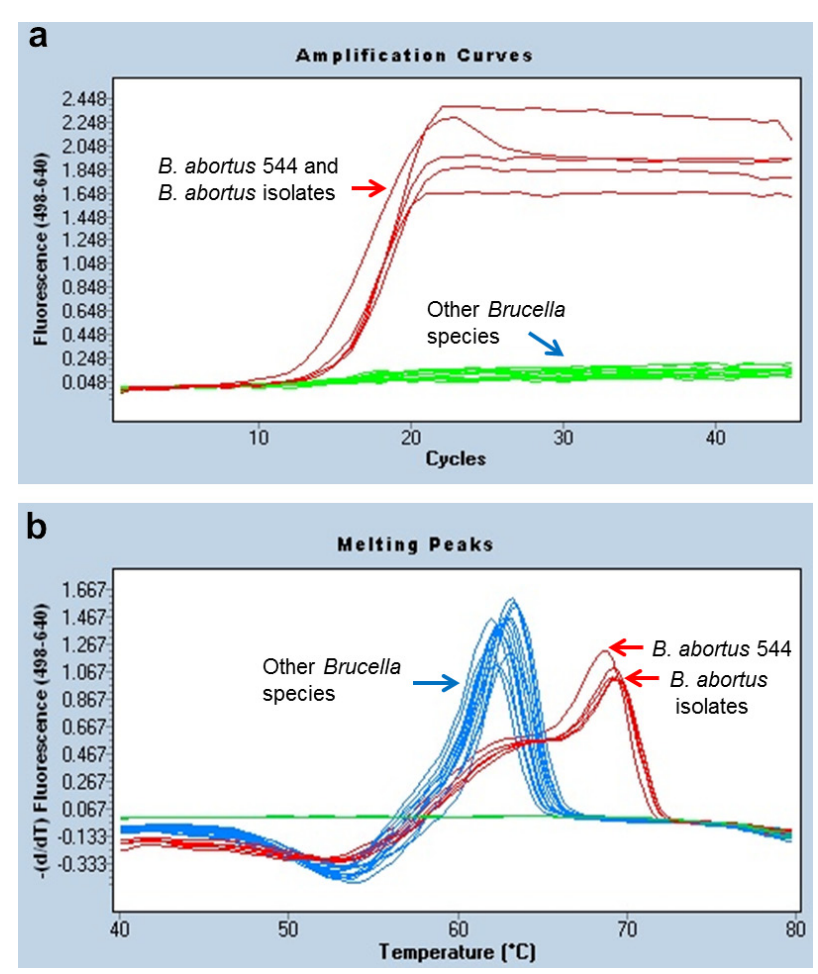

Fig. 1. Amplification curves (a) and melting peak analysis (b) in $B$. abortus 544 reference strain and Korean B. abortus isolates.

B. abortus reference strains (biovars 1-6 and 9) and B. abortus organisms from clinical specimens, whereas it yielded negative reactions to other Brucella species and non-Brucella bacterial strains (Table 1 and Fig. 1). Only B. abortus species showed specific amplification from approximately the 14th cycle (Fig. 1a). Additionally, the specific amplification was also confirmed by melting curve analysis. The $T m$ calling value of $B$. abortus reference strains and isolates was generated at $69^{\circ} \mathrm{C}$. In contrast with this finding, other Brucella species and non-Brucella strains showed less than a low melting peak at a temperature of $62^{\circ} \mathrm{C}$ (Fig. 1b). In the 16S rRNA PCR, some bacterial strains, such as Ochrabactrum anthropi and Staphlyococcus aureus, were diagnosed as positive reactions with the amplified product of $905 \mathrm{bp}$. BaSS-PCR showed different results depending on the biovar of B. abortus. In case of B. abortus bv. 1, 2 and 4, three specific bands (180 bp, $500 \mathrm{bp}$ and $800 \mathrm{bp}$ ) appeared, but other bvs. of $B$. abortus and other Brucella species showed only two bands (180 bp and $800 \mathrm{bp}$ ), and non-Brucella bacteria revealed only an $800 \mathrm{bp}$-band product as an internal control. Therefore, BaSS-PCR has the limitation of detecting B. abortus bv. 1,2 and 4 only, so B. abortus infection caused by other biovars could not be differentiated (Table 1).

The sensitivity of real-time PCR was assessed by means of successive 10-fold serial dilution of the genomic DNA of the $B$. abortus 544 reference strain, and it was revealed to be $20 \mathrm{fg} / \mu l$ (data not shown). In addition, the detection limit for B. abortus in the clinical samples was $4 \mathrm{CFU} / \mu l$. In contrast, a
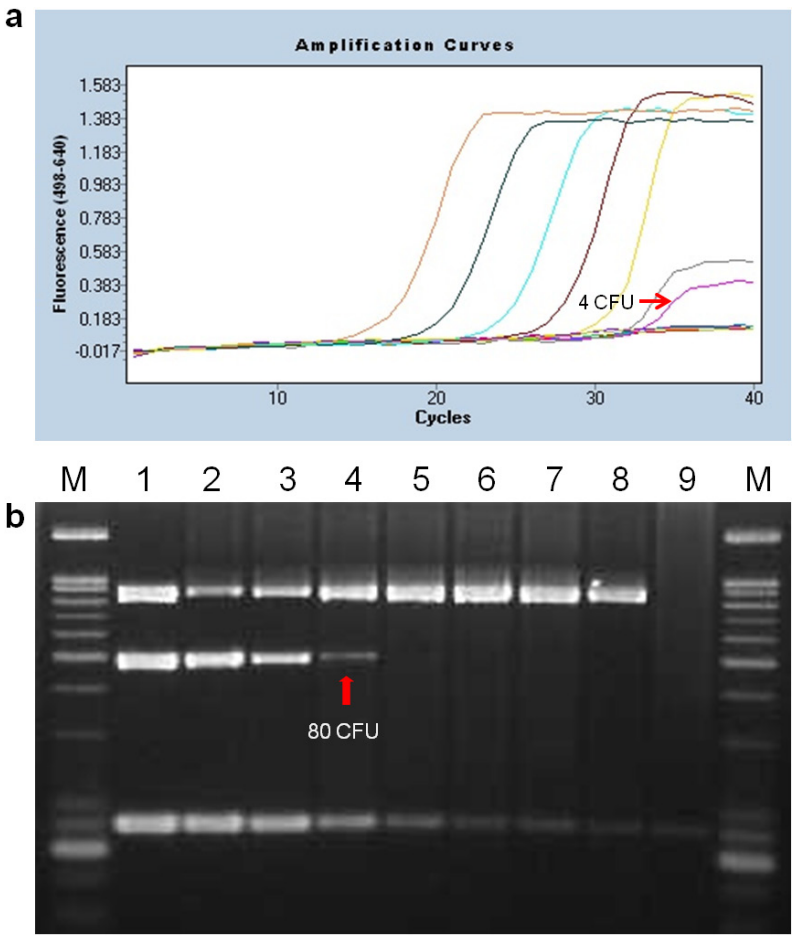

Fig. 2. Detection limits of the hybridization probe-based real-time PCR (a) and BaSS-PCR (b) determined by DNA extracted from lymphoid tissue inoculated with 10 -fold diluted $B$. abortus strains serially. (a) There were ranged from $4 \times 10^{6}$ to $4 \times 10^{-2} \mathrm{CFU} / \mu \mathrm{l}$. (b) M: 100-bp DNA ladder, lanes 1 to $7: 8 \times 10^{4}$ to $8 \times 10^{-2} \mathrm{CFU} /$ $\mu l$, lanes 8 and 9: internal and negative controls (D. W.).

the detection limit of conventional BaSS-PCR showed 80 $\mathrm{CFU} / \mu l$. Our new real-time PCR showed 20 times higher sensitivity than those with BaSS-PCR (Fig. 2), but equal sensitivity to $16 \mathrm{~S}$ rRNA PCR (data not shown).

In addition, the application of the real-time PCR to the clinical specimens was conducted using brucellosis-positive Korean native cattle. Here, B. abortus was isolated from tissue samples, such as various lymph nodes and buffy coats. All of the samples were confirmed as positive by generating a fluorescent signal during real-time PCR (Table 2). The range of mean $\mathrm{Ct}$ ranged between 28 and 30, except for buffy coat, and the $T m$ values were almost identical to the reference $B$. abortus 544 strain.

\section{DISCUSSION}

For decades, PCR-based assays have been developed continually as a form of real-time PCR. It is able to detect target microorganisms more sensitively, specifically and rapidly than conventional PCRs $[8,23]$. Unlike endpoint detection methods, such as agarose gel electrophoresis, real-time PCR is used for the quantitative measurement of amplified products using fluorescence during each PCR cycle. These reactions can be classified into two main types according to the fluorescent dye and the specificity of the PCR [15]. 
The former uses double-stranded DNA-intercalating dye (e.g., SYBR Green I), and the latter uses fluoroephores that bind to oligonucleotides. This type can be divided into three subtypes depending on the fluorescent molecules: (i) primerprobes; (ii) hydrolysis and hybridization probes; and (iii) analogs of nucleic acids [15]. First, SYBR Green I, as one of the most commonly used DNA-binding dyes, binds to total amounts of DNA generated during PCR, so it can induce specific and non-specific amplification $[15,22]$. At the same time, Taqman probe is a representative hydrolysis type, and it is designed to bind to a specific site of the target DNA, so it shows greater specificity than SYBR Green I. However, it has the disadvantage that the primer-dimer can be generated even if the primer design is not appropriate. Contrarily, hybprobe-based real-time PCR offers two main advantages: first, it requires two additional probes for binding, so it can show improved specificity to distinguish between closely related strains; second, hybprobe does not rely on the hydrolysis reaction, so melting curve analysis can be applied to differentiate based on the probe $\operatorname{Tm}[16,17]$. Thus, its application has increased in various fields, such as pathogen detection, SNP detection and so on $[11,15]$.

In particular, the application of SNPs in microbial molecular typing has been increasing in the diagnostic field. SNPs in the conserved region can be very strong markers for detecting and differentiating etiological agents specifically. Therefore, we designed a hybprobe from another B. abortusspecific SNP in the conserved $f b a A$ gene, although this gene had been already used in real-time PCR with Taqman probe [6].

With regard to specificity, only B. abortus strains revealed specific amplification curves from the 14th cycle, and $\mathrm{Tm}$ was $69^{\circ} \mathrm{C}$ in our new real-time PCR. Not only other Brucella species but also highly genetically and serologically related bacteria were not amplified. Especially, it yielded a negative reaction from two cross-reactive bacteria by $16 \mathrm{~S}$ rRNA PCR-O. anthropi and $S$. aureus $[1,9]$. In terms of sensitivity using $B$. abortus DNA, our real time PCR assay was equal to or higher than that of 16S rRNA PCR [20]. In addition, our new real-time PCR showed 20 times higher sensitivity and detected all biovars of $B$. abortus as compared with BaSSPCR (Table 1 and Fig. 2). Therefore, this new real-time PCR could be valuable for diagnosing $B$. abortus infection in terms of its accuracy, specificity and sensitivity.

Besides two conventional PCR assays, our new PCR showed improved analytical sensitivity, compared to other real-time PCR assays. Using serially diluted DNA samples, our assay revealed $20 \mathrm{fg}$, but two previous studies using 5'-nuclease IS711 yielded $150 \mathrm{fg}$ and $250 \mathrm{fg}$, respectively $[18,19]$. Additionally, previous real-time PCR based on the same $f b a$ gene reported sensitivity of $50 \mathrm{fg}$ or 15 cells [6], which was lower than in our study (20 fg or $4 \mathrm{CFU}$ ). However, Bounaadja et al. (2009) [2] reported a 10 times higher detection limit than our assay of $2 \mathrm{fg}$ using three genes (IS711, bcsp31 and per gene), but it was not from clinical samples only from extracted DNA samples. As with clinical specimens, our real-time PCR showed identical results to bacterial isolation with high specificity.
Because the genus Brucella is an intracellular bacterium, and the number of bacteria in specimens is usually small [23], a highly sensitive diagnostic technique is required to accurate differential diagnosis. This new real-time PCR could be very useful for directly diagnosing brucellosis caused by $B$. abortus in infected animals due to the high detection limit. In conclusion, our new real-time PCR based on hybprobe could be an efficient diagnostic technique with high sensitivity and rapidity for $B$. abortus-infected animals in the field, and it could also be applicable in public health.

ACKNOWLEDGMENT. This study was supported by a grant from the Animal and Plant Quarantine Agency (QIA) of the Ministry of Agriculture, Food and Rural Affairs (MAFRA) of the Republic of Korea during 2012-2014.

\section{REFERENCES}

1. Al-Ajlan, H. H., Ibrahim, A. S. and Al-Salamah, A. A. 2011. Comparison of different PCR methods for detection of Brucella spp. in human blood samples. Pol. J. Microbiol. 60: 27-33. [Medline]

2. Bounaadja, L., Albert, D., Chénais, B., Hénault, S., Zygmunt, M. S., Poliak, S. and Garin-Bastuji, B. 2009. Real-time PCR for identification of Brucella spp.: a comparative study of IS711, bcsp31 and per target genes. Vet. Microbiol. 137: 156-164. [Medline] [CrossRef]

3. Bricker, B. J., Ewalt, D. R., Olsen, S. C. and Jensen, A. E. 2003. Evaluation of the Brucella abortus species-specific polymerase chain reaction assay, an improved version of the Brucella AMOS polymerase chain reaction assay for cattle. J. Vet. Diagn. Invest. 15: 374-378. [Medline] [CrossRef]

4. Cloeckaert, A., Verger, J. M., Grayon, M. and Grépinet, O. 1995 Restriction site polymorphism of the genes encoding the major $25 \mathrm{kDa}$ and $36 \mathrm{kDa}$ outer-membrane proteins of Brucella. Microbiology 141: 2111-2121. [Medline] [CrossRef]

5. Ficht, T. A., Bearden, S. W., Sowa, B. A. and Marquis, H. 1990. Genetic variation at the omp 2 porin locus of the brucellae: species-specific markers. Mol. Microbiol. 4: 1135-1142. [Medline] [CrossRef]

6. Gopaul, K. K., Koylass, M. S., Smith, C. J. and Whatmore, A. M. 2008. Rapid identification of Brucella isolates to the species level by real time PCR based single nucleotide polymorphism (SNP) analysis. BMC Microbiol. 8: 86. [Medline] [CrossRef]

7. Gopaul, K. K., Sells, J., Lee, R., Beckstrom-Sternberg, S. M., Foster, J. T. and Whatmore, A. M. 2014. Development and assessment of multiplex high resolution melting assay as a tool for rapid single-tube identification of five Brucella species. BMC Res. Notes 7: 903. [Medline] [CrossRef]

8. Hinić, V., Brodard, I., Thomann, A., Holub, M., Miserez, R. and Abril, C. 2009. IS711-based real-time PCR assay as a tool for detection of Brucella spp. in wild boars and comparison with bacterial isolation and serology. BMC Vet. Res. 5: 22. [Medline] [CrossRef]

9. Horvat, R. T., El Atrouni, W., Hammoud, K., Hawkinson, D. and Cowden, S. 2011. Ribosomal RNA sequence analysis of Brucella infection misidentified as Ochrobactrum anthropi infection. $J$. Clin. Microbiol. 49: 1165-1168. [Medline] [CrossRef]

10. Kang, S. I., Her, M., Kim, J. W., Kim, J. Y., Ko, K. Y., Ha, Y. M. and Jung, S. C. 2011. Advanced multiplex PCR assay for differentiation of Brucella species. Appl. Environ. Microbiol. 77: 6726-6728. [Medline] [CrossRef] 
11. Lim, S. Y., Kim, B. J., Lee, M. K. and Kim, K. 2008. Development of a real-time PCR-based method for rapid differential identification of Mycobacterium species. Lett. Appl. Microbiol. 46: 101-106. [Medline]

12. López-Goñi, I., García-Yoldi, D., Marín, C. M., de Miguel, M. J., Muñoz, P. M., Blasco, J. M., Jacques, I., Grayon, M., Cloeckaert, A., Ferreira, A. C., Cardoso, R., Corrêa de Sá, M. I., Walravens, K., Albert, D. and Garin-Bastuji, B. 2008. Evaluation of a multiplex PCR assay (Bruce-ladder) for molecular typing of all Brucella species, including the vaccine strains. J. Clin. Microbiol. 46: 3484-3487. [Medline] [CrossRef]

13. Mayer-Scholl, A., Draeger, A., Göllner, C., Scholz, H. C. and Nöckler, K. 2010. Advancement of a multiplex PCR for the differentiation of all currently described Brucella species. $J$. Microbiol. Methods 80: 112-114. [Medline] [CrossRef]

14. McDonald, M., Dougall, A., Holt, D., Huygens, F., Oppedisano, F., Giffard, P. M., Inman-Bamber, J., Stephens, A. J., Towers, R., Carapetis, J. R. and Currie, B. J. 2006. Use of a singlenucleotide polymorphism genotyping system to demonstrate the unique epidemiology of methicillin-resistant Staphylococcus aureus in remote aboriginal communities. J. Clin. Microbiol. 44: 3720-3727. [Medline] [CrossRef]

15. Navarro, E., Serrano-Heras, G., Castaño, M. J. and Solera, J. 2015. Real-time PCR detection chemistry. Clin. Chim. Acta 439: 231-250. [Medline] [CrossRef]

16. Newby, D. T., Hadfield, T. L. and Roberto, F. F. 2003. Real-time PCR detection of Brucella abortus: a comparative study of SYBR green I, 5'-exonuclease, and hybridization probe assays. Appl. Environ. Microbiol. 69: 4753-4759. [Medline] [CrossRef]

17. Osińska, E., Golke, A., Słońska, A., Cymerys, J., Bańbura, M. W. and Dzieciatkowski, T. 2012. HybProbes-based real-time PCR assay for rapid detection of equine herpesvirus type 2 DNA. Pol. J. Vet. Sci. 15: 411-416. [Medline]

18. Probert, W. S., Schrader, K. N., Khuong, N. Y., Bystrom, S. L. and Graves, M. H. 2004. Real-time multiplex PCR assay for detection of Brucella spp., B. abortus, and B. melitensis. J. Clin. Microbiol. 42: 1290-1293. [Medline] [CrossRef]
19. Redkar, R., Rose, S., Bricker, B. and DelVecchio, V. 2001. Realtime detection of Brucella abortus, Brucella melitensis and Brucella suis. Mol. Cell. Probes 15: 43-52. [Medline] [CrossRef]

20. Romero, C., Gamazo, C., Pardo, M. and López-Goñi, I. 1995. Specific detection of Brucella DNA by PCR. J. Clin. Microbiol. 33: 615-617. [Medline]

21. Scott, J. C., Koylass, M. S., Stubberfield, M. R. and Whatmore, A. M. 2007. Multiplex assay based on single-nucleotide polymorphisms for rapid identification of Brucella isolates at the species level. Appl. Environ. Microbiol. 73: 7331-7337. [Medline] [CrossRef]

22. Smith, C. J. and Osborn, A. M. 2009. Advantages and limitations of quantitative PCR (Q-PCR)-based approaches in microbial ecology. FEMS Microbiol. Ecol. 67: 6-20. [Medline] [CrossRef]

23. Surucuoglu, S., El, S., Ural, S., Gazi, H., Kurutepe, S., Taskiran, P. and Yurtsever, S. G. 2009. Evaluation of real-time PCR method for rapid diagnosis of brucellosis with different clinical manifestations. Pol. J. Microbiol. 58: 15-19. [Medline]

24. The World Organisation for Animal Health (OIE) 2012. Bovine Brucellosis Chapter 2. 4. 3. OIE Terrestrial Manual 616-650.

25. Wareth, G., Melzer, F., Elschner, M. C., Neubauer, H. and Roesler, U. 2014. Detection of Brucella melitensis in bovine milk and milk products from apparently healthy animals in Egypt by real-time PCR. J. Infect. Dev. Ctries. 8: 1339-1343. [Medline] [CrossRef]

26. Whatmore, A. M., Davison, N., Cloeckaert, A., Al Dahouk, S., Zygmunt, M. S., Brew, S. D., Perrett, L. L., Koylass, M. S., Vergnaud, G., Quance, C., Scholz, H. C., Dick, E. J. Jr., Hubbard, G. and Schlabritz-Loutsevitch, N. E. 2014. Brucella papionis sp. nov., isolated from baboons (Papio spp.). Int. J. Syst. Evol. Microbiol. 64: 4120-4128. [Medline] [CrossRef]

27. Winchell, J. M., Wolff, B. J., Tiller, R., Bowen, M. D. and Hoffmaster, A. R. 2010. Rapid identification and discrimination of Brucella isolates by use of real-time PCR and high-resolution melt analysis. J. Clin. Microbiol. 48: 697-702. [Medline] [CrossRef] 